\title{
The Danish national type 2 diabetes cohort - the DD2 study
}

This article was published in the following Dove Press journal:

Clinical Epidemiology

14 September 2012

Number of times this article has been viewed

\author{
Henrik Toft Sørensen' \\ Søren Friborg ${ }^{2}$ \\ Jørgen Rungby ${ }^{3}$ \\ Jens Sandahl Christensen ${ }^{4}$ \\ Allan Vaag ${ }^{5}$ \\ Henning Beck-Nielsen ${ }^{6}$ \\ 'Department of Clinical Epidemiology, \\ Aarhus University Hospital, Aarhus, \\ ${ }^{2}$ Department of Endocrinology \\ M, Odense University Hospital, \\ Odense, Denmark, ${ }^{3}$ Department \\ of Pharmacology, University of \\ Aarhus, Aarhus, ${ }^{4}$ Department of \\ Internal Medicine and Endocrinology, \\ Aarhus University Hospital, Aarhus, \\ ${ }^{5}$ Department of Endocrinology, \\ Rigshospitalet and Copenhagen \\ University, ${ }^{6}$ Diabetes Research Centre, \\ Department of Endocrinology, Odense \\ University Hospital, Odense, Denmark
}

Correspondence: Henrik Toft Sørensen Department of Clinical Epidemiology, Aarhus University Hospital, Olof Palmes Allé 43-45, DK-8200,

Aarhus N, Denmark

$\mathrm{Tel}+4587168215$

Fax +45 87I 672I5

Email hts@dce.au.dk

\section{Editorial}

Type 2 diabetes is a pandemic and an enormous public health problem. This supplemental issue of Clinical Epidemiology describes the rationale, design, and implementation of the establishment of a large cohort of all Danes with type 2 diabetes (the DD2 study) and of a biobank to bridge the scientific disciplines of epidemiology, clinical medicine, genetics, epigenetics, and pharmacology. This will most likely result in great benefits for the application of evidence-based medicine to the care of, and improved outcomes for, Danish type 2 diabetes patients.

This real-life clinical scientific investment will be an international resource for diabetes research for many years to come. Type 2 diabetes is a rapidly growing disease affecting around 205 million people worldwide and, in a "worst case scenario", 439 million will be diagnosed with type 2 diabetes by the year $2025 .{ }^{1}$ The disease is associated with a two-fold increased mortality rate compared with the general population, due to complications such as myocardial infarction, stroke, gangrene in the lower extremities, end-stage renal failure, and blindness. The excess global mortality in 2000 attributable to diabetes overall, most of which was attributable to type 2 diabetes, was 2.9 million deaths. These complications are very troublesome for the individual diabetic patient and major public health problem.

Therefore, cost-effective national organization and intervention are strongly needed, both in order to prevent the disease, but also in an attempt to improve treatment of the metabolic abnormalities behind the disease with the aim of preventing the devastating complications.

Recent clinical trials ${ }^{2,3}$ have emphasized the importance of early intensive treatment of type 2 diabetes patients in order to prevent complications and improve quality of life. Therefore, evidence for new national guidelines for treatment and organisation for newly diagnosed type 2 diabetes patients is needed. In this case - if the guidelines are effective - the prognosis of newly diagnosed patients may be expected to improve significantly.

The overall aim of the DD2 study is to near-normalize metabolic control in newly diagnosed type 2 diabetes patients in order to prevent diabetic complications and improve quality of life. The DD2 study thus has two specific aims:

1. To investigate whether or not it is possible through treatment guidelines and structured organization to near-normalize the risk profile and to avoid/reduce diabetic complications by continuous monitoring through Danish health registries, thereby 
obtaining knowledge about predictors for the long-term outcome and thus objectives for new interventions.

2. To establish a biobank of DNA and plasma, urine, and tissue samples for individual characterization of type 2 diabetes patients that will improve the prognosis and build a platform for individualized treatment.

In Denmark the outcome of treatment and clinical course can be followed through comprehensive health registries with complete follow-up. ${ }^{4}$ Therefore the DD2 study will be able to evaluate treatment and intervene if the current treatment fails. Based on the data obtained, outcome will be evaluated prospectively, independently of the specific phenotypes and genotypes, and will thus be unbiased.

The identification of new genes and pathways involved in type 2 diabetes predisposition and increased risk of diabetic complications offers opportunities for developing novel therapeutic and preventative approaches. Furthermore, the identification of additional genetic variants - both protective and risk variants - may render it possible to use patterns of predisposition to tailor individual management of these conditions.

Denmark holds an internationally leading position within many aspects of clinical care and diabetes research, but such Danish research has been carried out in many institutions focusing on different aspects such as physiology, clinical medicine, health services research, biotechnology, clinical epidemiology, and biostatistics.

The pandemic of type 2 diabetes is showing no signs of abatement and therefore progress is urgently needed to slow progression and reduce the consequences. The establishment of a large cohort of all Danes with type 2 diabetes and of a biobank to bridge all scientific disciplines will be an important international resource for diabetes research for many years.

\section{Disclosure}

The authors report no conflicts of interest in this work.

\section{Acknowledgement}

DD2 is the acronym for 'The Danish Centre for Strategic Research in Type 2 Diabetes' supported by the Danish Agency for Science (grant no. 09-067009 and 09-075724). DD2 is also supported by The Danish Health and Medicines Authority, The Danish Diabetes Association and an unrestricted donation from Novo Nordisk A/S. The partners of the project are listed on the project website at "http://www.DD2.nu" It “_blank"www.DD2.nu.

\section{References}

1. Nolan CJ, Damm P, Prentki M. Type 2 diabetes across generations: from pathophysiology to prevention and management. Lancet. 2011;378:169-181.

2. Intensive blood-glucose control with sulphonylureas or insulin compared with conventional treatment and risk of complications in patients with type 2 diabetes (UKPDS 33). UK Prospective Diabetes Study (UKPDS) Group. Lancet. 1998;352:837-853.

3. Action to Control Cardiovascular Risk in Diabetes Study Group; Gerstein $\mathrm{HC}$, Miller ME, Byington RP, et al. Effects of intensive glucose lowering in type 2 diabetes. N Engl J Med. 2008;358:2545-2559.

4. Frank L. Epidemiology. When an entire country is a cohort. Science. 2000;287:2398-2399. 


\section{Supplementary data \\ DD2 organization}

Members of the executive committee

Professor Henning Beck-Nielsen, DMSc, Odense University Hospital

Professor Jørgen Rungby, DMSc, Aarhus University

Professor Henrik Toft Sørensen, DMSc, Aarhus University Hospital

Professor Jens Sandahl Christiansen, DMSc, FRCPI, Aarhus University Hospital

Professor Allan Vaag, DMSc, Copenhagen University

General practitioner Søren Friborg, Odense University Hospital

Members of the board

Professor Henning Beck-Nielsen, DMSc, Odense University Hospital, Denmark (Chariman)

Professor Jørgen Rungby, DMSc, Aarhus University, Denmark

Professor Henrik Toft Sørensen, DMSc, Aarhus University Hospital, Denmark

Professor Jens Sandahl Christiansen, DMSc, FRCPI, Aarhus University Hospital, Denmark

Professor Allan Vaag, DMSc, Copenhagen University, Denmark

Professor Bente Klarlund Pedersen, DMSc, Copenhagen University, Denmark

Professor Oluf Borbye Pedersen, DMSc, Hagedorn Research Institute, Gentofte, Denmark

Head of research, knowledge and courses Malene Bagger, MSc, PhD, The Danish Diabetes Association

Professor Ulf Smith, DMSc, Sahlgrenska University Hospital, Sweden, President EASD

Professor Philip Home, MA, PhD, DMSc, FRCP, Newcastle University, England

Professor Leif Groop, MD, PhD, Lund University, Sweden

Professor John Nolan, FRCPI, FRCP(Ed), CEO of Steno Diabetes Center, Gentofte, Denmark

Staff specialist Ole Andersen, DMSc, the Danish National Board of Health, Copenhagen, Denmark (observer)

Chief consultant Hanne Agerbak, the Danish Ministry of Health, Copenhagen, Denmark (observer)

Consultant Maj-Britt Laursen, Danish Regions, Copenhagen, Denmark (observer)

General practitioner Thomas Drivsholm, DMSc, PhD, The research unit for general practice, Copenhagen, Denmark

General practice coordinator Søren Friborg, MD, Odense University Hospital, Denmark

Chief medical officer Anders Dejgaard, MD, DMSc, Novo Nordisk A/S, Denmark

\section{Project management}

Project leader Jens Steen Nielsen, MSc, PhD, Odense University Hospital, Denmark

Communications consultant and coordinator Jane Jærndal, Odense University Hospital, Denmark

General practice coordinator Søren Friborg, MD, Odense University Hospital, Denmark 
Table SI Hospitals participating in DD2 (June 20I2)

\begin{tabular}{|c|c|c|}
\hline Hospital & Department & Responsible consultant \\
\hline Odense University Hospital & Dept of Endocrinology $M$ & $\begin{array}{l}\text { Henning Beck-Nielsen } \\
\text { Jan-Erik Henriksen }\end{array}$ \\
\hline Fredericia Hospital & Dept of Medicine & Hans Gjessing \\
\hline NBG_-Aarhus University Hospital & Dept of Medicine and Endocrinology & Jens Sandahl Christiansen \\
\hline Svendborg Hospital & Outpatient Dept of Diabete & Klaus Levin \\
\hline THG_Aarhus University Hospital & Dept of Medicine and Endocrinology & Jørgen Rungby \\
\hline Regional Hospital Viborg & Outpatient Dept of Endocrinology & Torben $\varnothing$ stergaard \\
\hline Hospital Unit Nyborg & Outpatient Dept of Endocrinology & Klaus Levin \\
\hline Vejle Hospital & Outpatient Dept of Medicine & Cramer Christensen \\
\hline Herlev Hospital & Dept of Medicine and Endocrinology & Henrik Westergaard \\
\hline Regional Hospital Silkeborg & Dept of Medicine & Klaus W Hansen \\
\hline Regional Hospital Randers & Clinic of Endocrinology $\mathrm{ClO}$ & Henning K Nielsen \\
\hline Bispebjerg Hospital & IC - Research & Hans Perrild \\
\hline Aalborg Hospital & Endocrinology Lab 2 Hospital West & Hans-Henrik Lervang \\
\hline Regional Hospital Horsens & Dept of Medicine & Lise-Lotte Fisker \\
\hline Hillerød Hospital & Dept of Cardiology and Endocrinology H 0652 & Michael Røder \\
\hline Steno Diabetes Center & Steno Diabetes Center & Peter Rossing \\
\hline Hospital Himmerland Farsø & Dept of Medicine & Henning S Rønne \\
\hline Sønderborg Hospital & Outpatient Dept of Diabetes (M43) & Hans R Rasmussen \\
\hline Regional Hospital Herning & Dept of Medicine & Nancy Kristensen \\
\hline
\end{tabular}

Table S2 Departments/outpatient clinics that have consented to participate in DD2, but have not yet referred any patients

\begin{tabular}{lll}
\hline Hospital & Department & Responsible consultant \\
\hline Rigshospitalet & Clinic of Medicine and Endocrinology & Allan Vaag \\
Aabenraa Hospital & Dept of Medicine & Jolanta Topolska \\
Haderslev Hospital & Dept of Medicine & Jolanta Topolska \\
Esbjerg Hospital & Dept of Medicine & Jeppe Gram \\
Hospital Vendsyssel & Dept of Medicine & Kim Helg Christiansen \\
Slagelse Hospital & Dept of Medicine & Henning Friis Juhl \\
Dronninglund Hospital & Center of Medicine Aalborg, Dronninglund \\
Frederiksberg hospital & Clinic of Cardiology and Endocrinology E & Grzegorz Jaroslaw Pacyk \\
Køge Hospital & Dept of Medicine & Anne Elisabeth Jarløv \\
Helsingør Hospital & Dept of Medicine & Leif Breum
\end{tabular}


Table S3 General practitioners participating in DD2 (June 2012)

\begin{tabular}{|c|c|}
\hline Name & Address \\
\hline Glamsbjerglægerne & Stensgårdsvej 20, 5620 Glamsbjerg \\
\hline Mogens Carl Petersen & Fynsvej 7, 6000 Kolding \\
\hline Lægerne Nørre Voldgade 58 & Nørrevoldgade 58, 5800 Nyborg \\
\hline Lægerne Willemoesvej & Willemoesvej 3I, 5700 Svendborg \\
\hline J.Ravn and M.Richert & Vestergade 2, 6640 Lunderskov \\
\hline Jacobilægerne & Ringkøbingvej 38, 6800 Varde \\
\hline Lægerne i Oksbøl & Torvegade 17, 6840 Oksbøl \\
\hline $\begin{array}{l}\text { Lili Tronegård-M. and Michael } \\
\text { Schmidt }\end{array}$ & Birkevej 2, 5300 Kerteminde \\
\hline Lægerne J B Winsløws Vej & $\begin{array}{l}\text { J.B. Winsløws Vej } 9 \text { A, } 5000 \\
\text { Odense C }\end{array}$ \\
\hline Lægehuset—Farum Midtpunkt & $\begin{array}{l}\text { Nygårdterrasserne 204, } 3520 \\
\text { Farum }\end{array}$ \\
\hline Lægekompagniskabet Venusvej 2 & Venusvej 2, 7000 Fredericia \\
\hline Paul Jørgen Schultz Aps & Hovedgaden Vest 86,6500 Vojens \\
\hline Lægerne Danmarksgade I3 & Danmarksgade 13, 7000 Fredericia \\
\hline Haarbylægerne & Møllevej 2, 5683 Hårby \\
\hline Lægerne i Nr. Lyndelse Aps & Carl Nielsensvej I, 5792 Årslev \\
\hline Lægerne i Østergade & Østergade I, 2., 5750 Ringe \\
\hline Larsen, Glenthøj and Nielsen & Birkevej 2, 5300 Kerteminde \\
\hline Claus Olesen and Elin Franck & Ny Vestergade I, I., 6000 Kolding \\
\hline Lægehuset Havnepladsen & Torvegade 16 A, 6800 Varde \\
\hline Lægeklinikken Østergade 10 & Østergade 10, St., 6500 Vojens \\
\hline Lægerne i Vindeby & Bregningevej 48, 5700 Svendborg \\
\hline Bylægen Peer Kirkebjerg & Skt. Anne Plads 2, 5000 Odense C \\
\hline Lægehuset i Rødding & Louisevej 13, 6630 Rødding \\
\hline Peter Larsen & $\begin{array}{l}\text { Skt. Anne Plads 4, I., } 5000 \\
\text { Odense C }\end{array}$ \\
\hline Lægerne i Harndrup & Skovvej 2, 5463 Harndrup \\
\hline Bente K. Bertelsen & Tvedgade 21, 6760 Ribe \\
\hline Lægehuset Aps. & Mellemgade 19 A, 5600 Faaborg \\
\hline Lone Manane and Bent Stolberg & Mommarkvej 259, 6470 Sydals \\
\hline Uwe Karstensen Aps & Låningen I, 6280 Højer \\
\hline
\end{tabular}

(Continued)
Table S3 (Continued)

\begin{tabular}{|c|c|}
\hline Name & Address \\
\hline Bau-Madsen, Fricke and Stavenuiter & Egevænget 4, 577I Stenstrup \\
\hline Dorothee Paul & Vidågade 48 , st. tv., 6270 Tønder \\
\hline Lægerne i Bjert & Gl. Bjært 26, 609I Bjert \\
\hline Peter G Petersen & Murtfeldts Plads 5, 6800 Varde \\
\hline Morten Toftager & Birkevej 2, 5300 Kerteminde \\
\hline Lægerne Vissingsgade 2I & Vissingsgade 21, 7100 Vejle \\
\hline Lægerne Kongensgade & $\begin{array}{l}\text { Kongensgade 27, 4., } 5000 \\
\text { Odense C }\end{array}$ \\
\hline Kim Rønhof & $\begin{array}{l}\text { Sankt Nicolai Gade 6, st., } \\
5700 \text { Svendborg }\end{array}$ \\
\hline Hanne Christensen & $\begin{array}{l}\text { Kongensgade 3, } 6070 \\
\text { Christiansfeld }\end{array}$ \\
\hline Lægehuset Nørre Aaby & $\begin{array}{l}\text { Æblehaven I, } 5580 \text { Nørre } \\
\text { Aaby }\end{array}$ \\
\hline Lægerne Englandsgade 8 & Englandsgade 8, 6700 Esbjerg \\
\hline Marianne Bov & $\begin{array}{l}\text { Skt. Anne Plads 2, I., } 5000 \\
\text { Odense C }\end{array}$ \\
\hline Stig Gerdes & $\begin{array}{l}\text { Danmarksgade II, I. tv., } 7000 \\
\text { Fredericia }\end{array}$ \\
\hline Carsten Winther Jakobsen & $\begin{array}{l}\text { Kongensgade } 38,2 \text {. th., } 5000 \\
\text { Odense C }\end{array}$ \\
\hline Bak og Larsen & $\begin{array}{l}\text { Teglgårdsparken 100, I., } 5500 \\
\text { Middelfart }\end{array}$ \\
\hline Lægerne Vestergade & Vestergade 2D, I., 6600 Vejen \\
\hline Berkjær, Iversen & $\begin{array}{l}\text { Bønløkke, Ellegaard Ulsnæs 4, } \\
6300 \text { Gråsten }\end{array}$ \\
\hline Søndersø Lægehus & Vesterled 2, 547I Søndersø \\
\hline Annemette Als & Kongevej 37, 6300 Gråsten \\
\hline Lægerne Jernbanegade & Jernbanegade 4, 7000 Fredericia \\
\hline Lægerne Syrenvej & 2 Syrenvej 2, 7080 Børkop \\
\hline Sundhedscenter Vejle & Nordås I7K, 7I00 Vejle \\
\hline Peter Mikael Klubien M D & Madsensvej 9,I, 3450 Allerød \\
\hline Lægeklinikken Danmarksgade & $\begin{array}{l}22 \text { Danmarksgade 22, } 7500 \\
\text { Holstebro }\end{array}$ \\
\hline
\end{tabular}

Clinical Epidemiology

\section{Publish your work in this journal}

Clinical Epidemiology is an international, peer-reviewed, open access journal focusing on disease and drug epidemiology, identification of risk factors and screening procedures to develop optimal preventative initiatives and programs. Specific topics include: diagnosis, prognosis, treatment, screening, prevention, risk factor modification, systematic

\section{Dovepress}

reviews, risk \& safety of medical interventions, epidemiology \& biostatical methods, evaluation of guidelines, translational medicine, health policies \& economic evaluations. The manuscript management system is completely online and includes a very quick and fair peer-review system, which is all easy to use. 